\title{
The Antennal Lobes of Fungus-Growing Ants (Attini): Neuroanatomical Traits and Evolutionary Trends
}

\author{
Christina Kelber Wolfgang Rössler Flavio Roces \\ Christoph Johannes Kleineidam \\ Department of Behavioral Physiology and Sociobiology, Biozentrum, University of Würzburg, Würzburg, Germany
}

\section{Key Words}

Attini $\cdot$ Leaf-cutting ants $\cdot$ Antennal lobes $\cdot$ Number of glomeruli $\cdot$ Macroglomerulus

\begin{abstract}
Ants of the tribe Attini are characterized by their obligate cultivation of symbiotic fungi. In addition to the complex chemical communication system of ants in general, substrate selection and fungus cultivation pose high demands on the olfactory system of the Attini. Indeed, behavioral studies have shown a rich diversity of olfactory-guided behaviors and tremendous odor sensitivity has been demonstrated. To allow fine-tuned behavioral responses, adaptations within the olfactory system of the Attini are expected. We compared the number, volumes and position of the glomeruli (functional units) of the antennal lobe of 25 different species from all three major Attini groups (lower, higher and leaf-cutting Attini). The antennal lobes of all investigated Attini comprise a high number of glomeruli ( $>257)$. The highest number (630) was found in Apterostigma cf. mayri. This species is at a basal position within the Attini phylogeny, and we suggest that a high number of glomeruli might have been advantageous in the evolution of the advanced olfactory systems of the Attini. In the leaf-cutting Attini, an extremely large glomerulus (macroglomerulus) near the antennal nerve entrance was recently described in two species. Preliminary results show that this macroglomerulus is in-
\end{abstract}

volved in processing of trail-pheromone information. In our comparative study, we find this macroglomerulus in all investigated leaf-cutting Attini, but in none of the lower and higher Attini species. It is found only in large workers, and for all investigated species it is located close to the entrance of the antennal nerve. Our results indicate that the presence of a macroglomerulus in large workers of leaf-cutting Attini is a derived over-expression of a trait in the polymorphic leaf-cutting species. It presumably represents an olfactory adaptation to elaborate foraging and mass recruitment systems, and adds to the complexity of division of labor and social organization known for this group.

Copyright $\odot 2009$ S. Karger AG, Basel

\section{Introduction}

The tribe Attini is a monophyletic taxon with 13 genera and over 230 species restricted to the new world. Based on studies of behavioral ecology [Weber, 1956; Wilson, 1971; Hölldobler and Wilson, 1990], larval morphology [Schultz and Meier, 1995], and mDNA sequence analyses [Wetterer et al., 1998] three major groups are distinguished. The first group comprises the lower (for-

Grant Sponsor: German Science Foundation DFG; Grant number: SFB 554 (A6), University of Würzburg.

\section{KARGER}

Fax +41613061234 E-Mail karger@karger.ch www.karger.com (c) 2009 S. Karger AG, Basel

0006-8977/09/0734-0273\$26.00/0

Accessible online at:

www.karger.com/bbe
Christina Kelber

Department of Behavioral Physiology and Sociobiology, Biozentrum

University of Würzburg, Am Hubland

DE-97074 Würzburg (Germany), Tel. +49 9318884 336, Fax +49 9318884309

E-Mail christina.kelber@biozentrum.uni-wuerzburg.de 
merly basal) Attini with nine different genera and small colonies housing only several hundred individuals. The second group, the higher (formerly intermediate) Attini contains the two genera Sericomyrmex and Trachymyrmex with colony sizes restricted to several thousands of individuals [Weber, 1972; Hölldobler and Wilson, 1990]. The last group, the leaf-cutting Attini, comprises two genera, Atta and Acromyrmex, with colonies composed of up to millions of individuals. A recent phylogenetic study allows a more detailed separation of species groups based on their agricultural systems [Schultz and Brady, 2008], but the basic division in three major groups remains unchanged.

All Attini species are characterized by an obligate cultivation of symbiotic fungi; an association which originated 45-60 million years ago in the early Tertiary. Since then, the success of fungus gardening improved by the coevolution of both partners - the ants and the fungus and includes derived fungus-care procedures by the ants, such as fertilization, and the use of antibiotic substances [Currie et al., 1999; Mueller et al., 2001]. The complexity of resource selection and fungus cultivation are expected to pose high demands on the Attini olfactory system. Furthermore, chemical communication along the foraging trails and the evolution of complex foraging systems add to the multitude of relevant odors in the life of Attini ants.

The three Attini groups differ in both the food resources and the foraging strategies they use. The fungus of lower and higher Attini colonies is reared mainly with insect carcasses, feces, dead plant parts, and to a lesser extent with living plant tissue [Weber, 1972; Hölldobler and Wilson, 1990; Mueller and Wcislo, 1998; Mackay et al., 2004]. The small body size and the small mandibles of lower and of most higher Attini workers are unsuited to cut fresh leaves [Wilson, 1980a, b]. In the leaf-cutting Attini, the worker caste shows a pronounced size-polymorphism, and the division of labor is largely dependent on worker size (alloethism). Large workers are equipped with powerful mandibles suited to cut and transport fresh leaves and grasses [Weber, 1972; Roces and Lighton, 1995; Röschard and Roces, 2002], thus a huge and renewable food source stands open for the leaf-cutting Attini. Important for the utilization of this resource is an efficient mass recruitment system. Indeed, the majority of leaf-cutting Attini forage on well established pheromone trails that are even physically maintained, and division of labor can be observed along transport chains on the trail [Röschard and Roces, 2003]. In contrast, lower Attini workers forage alone or in small groups [Weber, 1972;
Leal and Oliveira, 2000]. We expect that all fungus-growing Attini have a highly developed olfactory system, necessary to meet the demands of complex olfactory-guided tasks such as pheromone communication or substrate selection. Indeed, several behavioral studies show how sensitive and fine-tuned the odor responses in leaf-cutting Attini are [Tumlinson et al., 1972; Andryszak et al., 1990; Kleineidam et al., 2005, 2007; Morgan et al., 2006]. We expect that the demands on the olfactory system of fungus growing Attini differ among the different groups according to differences in olfactory-guided behaviors such as foraging strategies and the use of chemical mass recruitment.

In ants - as in other insects - axons of antennal olfactory receptor neurons (ORNs) project to the first olfactory neuropil, the antennal lobe $(\mathrm{AL})$ in the brain and terminate in the functional units of the $\mathrm{AL}$, the glomeruli. For both vertebrate and invertebrate olfactory systems, it is assumed that axons from ORNs that express the same odorant receptor gene converge onto the same glomerulus [Rodrigues, 1988; Vassar et al., 1994; Mombaerts et al., 1996]. This is supported by a good match in the number of functional odorant receptor genes and the number of glomeruli found in the AL, as shown for example in the honeybee Apis mellifera or in Drosophila [Vosshall et al., 2000; Robertson and Wanner, 2006]. This organization results in a spatial representation of odors in the AL glomeruli, which was documented by functional calcium-imaging studies, especially in the honeybee, and more recently in the carpenter ant Camponotus floridanus [Joerges et al., 1997; Galizia et al., 1999b; Sachse et al., 1999; Zube et al., 2008].

The olfactory system in social Hymenoptera shows some interesting peculiarities compared to the olfactory system in other insects [Kleineidam and Rössler, 2009]. Individual olfactory sensilla on the antennae are generally equipped with a high number of ORNs [Schneider and Steinbrecht, 1968; Esslen and Kaissling, 1976; Kelber et al., 2006] compared, for example, to moths or flies that have only one to three receptor neurons in a single sensillum. The advantages of multiple ORNs are not yet clear. Another difference is the high number of glomeruli in the AL. Glomerular numbers in most insects studied so far do not exceed 100, for example $\sim 43$ glomeruli in Drosophila melanogaster, $\sim 50$ glomeruli in the mosquito Aedes aegypti, and $\sim 65$ in Manduca sexta [Stocker, 1994; Laissue et al., 1999; Huetteroth and Schachtner, 2005; Ignell et al., 2005], whereas the number of glomeruli in social Hymenoptera ranges from $\sim 164$ in the honeybee Apis mellifera and up to $\sim 460$ in the Carpenter ant Cam- 
ponotus floridanus [Arnold et al., 1985; Flanagan and Mercer, 1989; Galizia et al., 1999a; Zube et al., 2008]. It seems that the high number of glomeruli in social insects is related to the diverse demands on the olfactory system and possibly reflects the high level of social organization based on olfactory communication using pheromones and chemical recognition cues.

Regarding the size of the glomeruli in the AL, striking differences can be found. Exceptionally large glomeruli (macroglomeruli, MG) have been found in moths, but also in males of social Hymenoptera [Arnold et al., 1985; Hansson and Anton, 2000] and these MG were shown to process information about sex pheromones [Arnold et al., 1985; Sandoz, 2006]. Because the size of a glomerulus is mainly determined by the number of ORN axons terminating in it, individual AL glomeruli can be considered as a trait, and a large glomerulus or MG is likely to represent an over-representation of a particular trait. Large glomeruli might also reflect the importance of an odor, which was shown to be the case for sex pheromone-specific MG. Recently, an MG was described in the AL of large leaf-cutting ant workers of Atta vollenweideri and Atta sexdens [Kleineidam et al., 2005]. Preliminary physiological data show that olfactory information about the trail pheromone is represented in this MG [Kleineidam, unpublished results].

In this study we investigate the neuroanatomy of the AL in many species across all three major Attini groups to reveal potential differences in the glomerular organization. The selected species differ in life history, behavioral ecology and olfactory-guided behavior, and we compare several aspects of the AL: the number of glomeruli, their size and their position. This study is designed to gain new insights into the evolution of an important brain compartment by a comparison of many species within a monophyletic taxon.

\section{Material and Methods}

We investigated workers of 25 Attini species, both from laboratory colonies as well as from field colonies in Central and South America. The species investigated, their origin and the major AL parameters analyzed are summarized in table 1.

\section{Fixation and Preparation}

We used specimens fixed and stored under different conditions. Some of the specimens were fixed as whole animals in an alcoholic Bouin solution (0.9\% Picric acid, $40 \%$ formaldehyde, $4.8 \%$ glacial acetic acid in $70 \%$ ethyl alcohol) and then stored in $70 \%$ ethanol. For other specimens, the perforated heads were fixed in a mixture of $2 \%$ glutaraldehyde and $2 \%$ paraformalde- hyde (fix-mix) or in a solution containing $4 \%$ paraformaldehyde in phosphate-buffered saline (PBS, pH 7.2). For all specimens, the head width was measured between the outer edges of the eyes. Afterwards, heads were cut open and the brains were dissected in saline solution (127 mM NaCl, $7 \mathrm{mM} \mathrm{KCl}, 1.5 \mathrm{mM} \mathrm{CaCl}_{2}, 0.8 \mathrm{mM}$ $\mathrm{Na}_{2} \mathrm{HPO}_{4}, 0.4 \mathrm{mM} \mathrm{KH}_{2} \mathrm{PO}_{4}$, $4.8 \mathrm{mM}$ TES, $3.2 \mathrm{~mm}$ Trehalose). For specimens collected from laboratory colonies, the head was cut off immediately after removing these workers from the colony and the brains were also dissected in saline solution.

After dissection, the brains were immediately transferred to ice-cold fix-mix and then stored for 5-7 days at $4^{\circ} \mathrm{C}$. Brains were then rinsed in PBS (3 times for $10 \mathrm{~min}$ ), dehydrated in an ascending series of ethanol $(50,70,80,90$, and $95 \%$ and 2 times 100\%, 10 min each) and finally transferred to methylsalicylic acid (M-2047, Sigma-Aldrich, Steinheim, Germany). Glutaraldehyde fixation intensifies the autofluorescence of the brain and allows confocal analyses and 3D-reconstructions of neuropiles without any additional staining. The brains were examined with a laser-scanning confocal microscope $(20 \times 0.7$ NA lens, Leica TCS SP2 AOBS, Leica Microsystems AG, Wetzlar, Germany).

\section{Antennal Lobe Anatomy across 25 Species}

The number and the volume of all glomeruli in a single AL were determined for all investigated species by $3 \mathrm{D}$ reconstruction of all glomeruli with the help of the 3D software AMIRA 3.1.1 (Mercury Computer Systems, Berlin, Germany). Prior to the 3Dreconstructions, we inspected visually the confocal image stacks of the ALs to ensure adequate image quality. For most species, confocal stacks of 2-4 specimens were selected for detailed investigation and one was chosen for reconstruction. The other stacks were examined for the existence of, for example, an extremely large glomerulus, but no $3 \mathrm{D}$ reconstruction was made (see table 1). Each glomerulus in the AL was labeled individually in all three planes (xy, xz, yz) and subsequently reconstructed by using the wrapping function of AMIRA 3.1.1. The antennal nerve was reconstructed as a landmark for the comparison of the position of glomeruli in different species. Subsequently, we measured the volume of each glomerulus and the total number of glomeruli in the AL.

\section{Classification of a Macroglomerulus}

Across all investigated species and also across workers within polymorphic species, the size of the AL and its glomeruli varied considerably. In order to compare the size of glomeruli among different ALs, we used a relative measure based on the variance found in all (or a large subset of) glomeruli. First, the volume of glomeruli obtained from the $3 \mathrm{D}$ reconstructions was used to calculate the radius of a sphere having the same volume as the glomerulus. Second, the mean radius $\left(\mathrm{R}_{\mathrm{M}}\right)$ of these spheres and the standard deviation (SD) were calculated. Third, for the largest and the second largest radius $\left(R_{L}\right.$ and $\left.R_{S}\right)$, the radius value $\left(R_{V}\right)$ was calculated using: $R_{V}=\left(R_{L}-R_{M}\right) / S D$. We used the calculated radii of the glomerular volumes because the size distribution based on volumes is skewed, whereas the size distribution based on the radii is normally distributed. Our measure of $R_{V}$ describes how much bigger the largest (second largest) glomerulus is compared to the mean size of a glomerulus and with respect to the variance of glomerular volumes. We defined a glomerulus as a macroglomerulus if its radius was $5 \times \mathrm{SD}$ larger than the mean radius of the glomeruli of the $\mathrm{AL}\left(\mathrm{MG}: \mathrm{R}_{\mathrm{V}}>5\right)$. 
Table 1. Investigated Attini species and the major antennal lobe parameters analyzed

\begin{tabular}{|c|c|c|c|c|c|c|c|c|c|c|c|c|}
\hline Species & Type & Origin & Date & Fix. & $\begin{array}{l}\text { Head } \\
\text { width } \\
\mathrm{mm}\end{array}$ & 3D-R. & No. & $\begin{array}{l}\text { Vol. } \\
\text { min } \\
\mu \mathrm{m}^{3}\end{array}$ & $\begin{array}{l}\text { Vol. } \\
\text { max. } \\
\mu \mathrm{m}^{3}\end{array}$ & $\mathrm{R}_{\mathrm{v}}$ & $\begin{array}{l}\text { AL Vol. } \\
\mu \mathrm{m}^{3}\end{array}$ & $\begin{array}{l}\mathrm{AL} / \\
\mathrm{OL}\end{array}$ \\
\hline \multicolumn{13}{|l|}{ Leaf-cutting Attini } \\
\hline Atta cephalotes & 1 & Panama & 2003 & fix-mix & 2.29 & $1(2)$ & 349 & 922 & 36,651 & 7.5 & $1,262,390$ & 5.83 \\
\hline Atta colombica & 1 & Panama & 2003 & fix-mix & 2.0 & $1(2)$ & 411 & 777 & 40,161 & 6.8 & $1,707,621$ & 5.89 \\
\hline Atta texana & $\mathrm{f}$ & USA & 2007 & fix-mix & 1.34 & $1(2)$ & 336 & 1086 & 42,173 & 7.2 & $1,709,900$ & 4.80 \\
\hline Atta laevigata & 1 & Brazil & 2005 & fix-mix & 2.96 & $2(1)$ & 452 & 500 & 47,019 & 7.0 & $1,897,535$ & - \\
\hline Atta sexdens & 1 & Brazil & 2002 & fix-mix & 2.16 & $1(2)$ & 382 & 646 & 32,520 & 7.0 & $1,125,748$ & 5.13 \\
\hline Atta capiguara & $\mathrm{f}$ & Brazil & 2007 & fix-mix & 2.4 & $1(1)$ & 389 & 724 & 47,645 & 6.6 & $1,690,539$ & 5.21 \\
\hline Atta vollenweideri & 1 & Argentina & 2005 & fix-mix & 2.56 & $6(10)$ & 450 & 165 & 16,575 & 6.1 & 707,377 & 4.90 \\
\hline Atta bisphaerica & $\mathrm{f}$ & Brazil & 2007 & fix-mix & 2.64 & $1(1)$ & 406 & 412 & 27,564 & 6.7 & $1,020,307$ & - \\
\hline Acromyrmex ambiguus & 1 & Uruguay & 2003 & fix-mix & 1.89 & $1(3)$ & 409 & 418 & 22,210 & 6.7 & 961,455 & 7.36 \\
\hline Acromyrmex lundi & 1 & Argentina & 1997 & fix-mix & 1.03 & $1(1)$ & 477 & 451 & 30,448 & 6.2 & $1,579,262$ & 15.84 \\
\hline Acromyrmex octospinosus & 1 & Costa Rica & 1995 & fix-mix & 2.08 & $1(1)$ & 438 & 465 & 30,655 & 6.4 & $1,544,938$ & 8.70 \\
\hline Acromyrmex fracticornis & $\mathrm{f}$ & Argentina & 2008 & fix-mix & 2.4 & $1(2)$ & 437 & 575 & 24,629 & 6.3 & $1,260,251$ & - \\
\hline Acromyrmex heyeri & 1 & Uruguay & 2000 & fix-mix & 1.99 & $1(1)$ & 459 & 416 & 35,411 & 7.7 & $1,422,295$ & 12.99 \\
\hline Acromyrmex balzani & $\mathrm{f}$ & Brazil & 2007 & fix-mix & 2.16 & $1(2)$ & 400 & 667 & 33,445 & 5.9 & $1,512,781$ & - \\
\hline Acromyrmex striatus & f & Argentina & 2006 & fix-mix & 1.48 & $2(2)$ & 369 & 405 & 13,205 & 5.8 & 628,966 & 3.89 \\
\hline \multicolumn{13}{|l|}{ Higher Attini } \\
\hline Sericomyrmex amabilis & 1 & Panama & 2007 & fix-mix & 1.08 & $1(1)$ & 344 & 424 & 5,853 & 4.5 & 476033 & 9.34 \\
\hline Trachymyrmex cornetzi & 1 & Panama & 2007 & fix-mix & 0.8 & $1(1)$ & 363 & 81 & 1,490 & 4.4 & 121733 & - \\
\hline Trachymyrmex septentrionalis & $\mathrm{f}$ & USA & 1993 & Bouin & 1.02 & $1(2)$ & 362 & 312 & 6,846 & 4.2 & 549439 & 7.25 \\
\hline \multicolumn{13}{|l|}{ Lower Attini } \\
\hline Mycetosiritis cf. hartmanni & $\mathrm{f}$ & Costa Rica & 1995 & Bouin & 0.68 & $1(1)$ & 309 & 146 & 3,285 & 4.2 & 229,412 & - \\
\hline Mycetophylax conformis & $\mathrm{f}$ & Trinidad & 1995 & Bouin & 0.59 & $1(1)$ & 288 & 234 & 5,009 & 4.4 & 283,656 & 8.15 \\
\hline Cyphomyrmex costatus & 1 & Panama & 2007 & fix-mix & 0.52 & $1(1)$ & 257 & 161 & 2,281 & 3.7 & 142,993 & - \\
\hline Cyphomyrmex minutus & $\mathrm{f}$ & USA & 2001 & Bouin & 0.61 & $1(1)$ & 364 & 245 & 3,600 & 4.7 & 290,100 & - \\
\hline Apterostigma cf. mayri & $\mathrm{f}$ & Panama & 1995 & Bouin & 0.64 & $1(2)$ & 630 & 97 & 4,888 & 4.1 & 469,871 & 17.17 \\
\hline Mycocepurus smithi & $\mathrm{f}$ & Costa Rica & 1995 & Bouin & 0.62 & $1(2)$ & 461 & 108 & 2,058 & 4.4 & 206,685 & 6.97 \\
\hline Mycocepurus sp. & $\mathrm{f}$ & Costa Rica & 1995 & Bouin & 0.64 & $1(1)$ & 360 & 127 & 1,074 & 2.8 & 144,779 & 6.17 \\
\hline
\end{tabular}

Species: affiliation of investigated workers to one of the three Attini groups [Wetterer et al., 1998; Schultz and Brady, 2008] Type: laboratory (l) or field (f) colony; Origin: country, where colony or founding queen was collected; Date: year, when founding queen (laboratory colonies) or workers (field colonies) were collected; Fix: used fixation method, either fixation with Bouin solution or fix-mix; Head width: measured head width from eye to eye of the reconstructed worker; 3D-R: number of 3D-reconstructed antennal lobes and manually inspected antennal lobes (in brackets); No.: number of glomeruli found in the antennal lobe; Vol. min: volume of smallest glomerulus; Vol. max: volume of largest glomerulus; $\mathrm{R}_{\mathrm{v}}$ : radius volume of largest glomerulus; AL Vol.: Volume of all glomeruli in the antennal lobe; AL/OL: ratio of antennal lobe volume and optic lobe volume.
A Macroglomerulus in Leaf-Cutting Attini

We found an MG only in leaf-cutting Attini, which all have a polymorphic worker caste. The position of the MG in the AL was described by using the antennal nerve as a landmark. We compared the positions to the two already known positions of the MG in $A$. sexdens and A. vollenweideri [Kleineidam et al., 2005]. Additionally, we investigated the ALs of small leaf-cutting Attini workers (head width $<1 \mathrm{~mm}$ ) in search of an MG. Therefore a subset of 100 glomeruli near the antennal nerve entrance was reconstructed in the AL of small workers of four Atta species (A. vollenweideri, A. colombica, A. laevigata and A. cephalotes) and five Acromyrmex species (Ac. striatus, Ac. ambiguus, Ac. fracticornis, Ac. heyeri and Ac. lundi).

\section{Results}

We measured the number, size and position of all glomeruli in the AL of 25 Attini species. For most species the fixation with either Bouin or fix-mix resulted in confocal scans of good quality and the glomeruli in the ALs could be distinguished easily for 3D reconstruction (fig. 1D-I). Even specimens stored in Bouin for several years allowed confocal scans of reasonable quality (fig. 1D). We found a large variability in the number of glomeruli within the Attini. An MG was found only in 


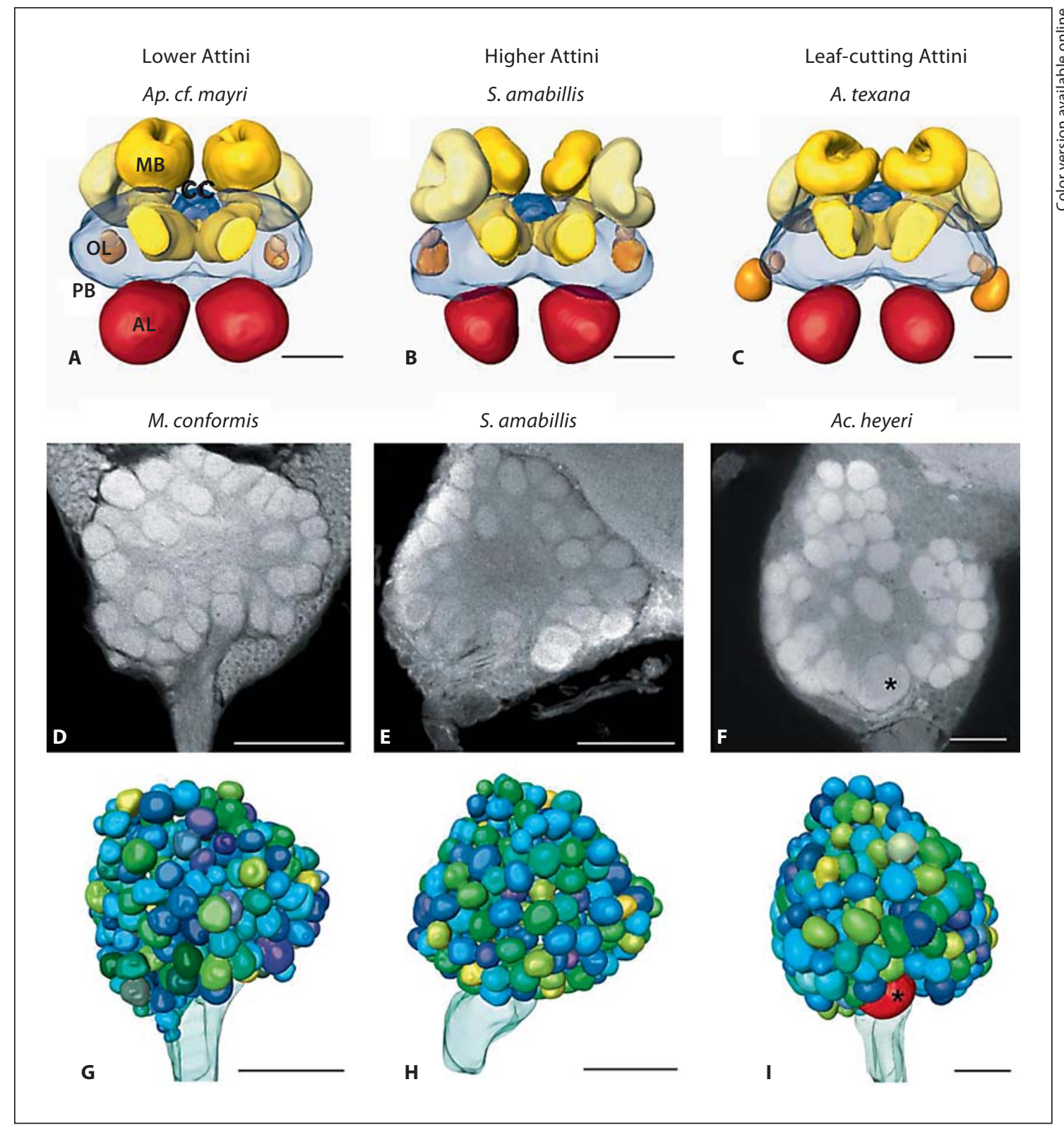

Fig. 1. Antennal lobes of lower, higher and leaf-cutting Attini. 3D reconstructions of the brains $(\mathbf{A}-\mathbf{C})$, single confocal slices of the antennal lobes $(\mathbf{D}-\mathbf{F})$, and $3 \mathrm{D}$ reconstructions of the antennal lobes (G-I) of different Attini species. For the lower Attini, the brain of Apterostigma cf. mayri is shown (A); the second brain belongs to Sericomyrmex amabilis as an example of the higher Attini (B); the third brain belongs to Atta texana, a leaf-cutting Attini species (C). The confocal images show the ALs of Mycetophylax conformis (D), Sericomyrmex amabilis (E) and Acromyrmex heyeri $(\mathbf{F})$ at a position close to the antennal nerve entrance. $\mathbf{G}, \mathbf{H}$ and I show complete $3 \mathrm{D}$ reconstructions based on confocal image stacks of the antennal lobes shown above. No MG was found in either the lower or higher Attini. In the leaf-cutting Attini species Acromyrmex heyeri the MG is clearly visible in the confocal section $\left({ }^{*}\right)$ and in the $3 \mathrm{D}$ reconstruction. $\mathrm{AL}=$ Antennal lobe; $\mathrm{CC}=$ central complex; $\mathrm{MB}=$ mushroom bodies; $\mathrm{OL}=$ optic lobe; $\mathrm{PB}=$ protocerebrum. Scales: $100 \mu \mathrm{m}$ in A-C, $50 \mu \mathrm{m}$ in D-I. 
leaf-cutting Attini and in all cases it was positioned close to the antennal nerve entrance.

\section{Number of Glomeruli}

One outstanding character of the ALs in all Attini is the high number of glomeruli. In the five investigated genera of the lower Attini we found between 257 glomeruli in $C$. costatus and 630 glomeruli in Ap. cf. mayri (table 1). The large range in the number of glomeruli illustrates the high variation of this character within the Attini. For the higher and leaf-cutting Attini, both groups consist of only two genera and in all four genera we found a similar number. For the higher Attini, we found 344 glomeruli in S. amabilis, 362 glomeruli in T. septentrionalis, and 363 in T. cor$n e t z i$. For the large workers of leaf-cutting Attini, we found between 369 glomeruli (Ac. striatus) and 477 glomeruli (Ac. lundi) in Acromyrmex, and a similar range - between 336 glomeruli (A. texana) and 452 glomeruli (A. laevigata) in Atta. In all species, the basic organization of the $\mathrm{AL}$ seems to be similar, although there are large differences in the glomerular number. The antennal nerve enters the AL and divides into several sensory tracts, in which the axons of the receptor neurons are bundled until they terminate in their target glomerulus. In most species, no glomeruli are located in the core of the AL. The somata of interneurons and projection neurons are located in several clusters on the outer part of the AL.

\section{Size of Glomeruli}

The size of the glomeruli ranged from 97 to $5,009 \mu \mathrm{m}^{3}$ in the lower Attini, from 81 to $6,846 \mu \mathrm{m}^{3}$ in the higher Attini, and from 165 to $47,645 \mu^{3}$ in the large workers of leaf-cutting Attini (table 1). A single and very large glomerulus was found in large workers of leaf-cutting Attini (head width between 1.03 and $2.96 \mathrm{~mm}$ ) and it extended the range of glomerular volumes considerably. This glomerulus is about 10-14 times larger than the volume of average-sized glomeruli. Within the ALs of lower and higher Attini, no glomerulus with such an extreme volume was detected. As a size measure for the largest glomeruli of an AL, we calculated the radius value $\left(\mathrm{R}_{\mathrm{v}}\right)$ which refers to the variance of all glomerular volumes found in the AL. In all investigated Attini species, the second largest glomeruli have a $\mathrm{R}_{\mathrm{v}}$ between 2 and 5 and therefore are not considered to be extremely large glomeruli. The largest glomeruli in the AL of lower and higher Attini have an only marginally larger $R_{v}$, whereas the largest glomeruli in all leaf-cutting Attini have a $\mathrm{R}_{\mathrm{v}}$ larger than 5 (ranging from 5.8 to 7.7; fig. 2A). The difference in the $\mathrm{R}_{\mathrm{v}}$ of the largest and second largest glomerulus in leaf-cutting Attini illustrates that only the largest glomerulus has an extreme volume and henceforth is called macroglomerulus (MG). The least prominent MGs were found in Ac. striatus and Ac. balzani, and none of the investigated lower and higher Attini posses an MG. The prominent size and position of the MGs enabled us to identify them by visual inspection of confocal stacks which were used to confirm our results.

\section{Position of the Macroglomerulus}

Kleineidam et al. [2005] showed that the MG in A. vollenweideri and $A$. sexdens are located in species-specific configuration close to the antennal nerve entrance. In A. vollenweideri, the MG was found adjacent to the antennal nerve, whereas in $A$. sexdens, it was positioned more medial with one normally sized glomerulus in between the nerve and the MG. We analyzed the MG position in other Atta and Acromyrmex species. By visual inspection we found that the MG in different Atta and Acromyrmex species were adjacent to the antennal nerve (similar to the position found in A. vollenweideri): in A. laevigata, A. texana, A. capiguara and A. bisphaerica and furthermore in Ac. ambiguus, Ac. heyeri (fig. 1F, I), Ac. lundi, Ac. octospinosus and Ac. striatus. The MG-position with one regular glomerulus in between (similar to the position in A. sexdens) was found in A. cephalotes, A. colombica, and Ac. balzani.

\section{A Macroglomerulus in Large and Small Workers?}

Small workers (head width $<1 \mathrm{~mm}$ ) in A. vollenweideri and $A$. sexdens do not possess an MG [Kleineidam et al., 2005]. We analyzed whether this size-based difference is unique to Atta species, or whether it also exists in the less polymorphic Acromyrmex species. We therefore compared the $\mathrm{R}_{\mathrm{V}}$ of the largest and second largest glomeruli to a subset of 100 glomeruli at the comparable part of the AL in nine different Atta and Acromyrmex species with head widths ranging from 0.68 to $0.88 \mathrm{~mm}$ (fig. 2B). In addition to the specimens in which glomeruli were reconstructed, we inspected several confocal stacks visually. Both visual inspection and volume analyses clearly showed that small workers of all investigated Atta and Acromyrmex species do not possess an MG.

\section{Discussion}

We investigated the ALs of more than $10 \%$ of the approximately 230 extant Attini from all three groups (lower, higher and leaf-cutting Attini). Our aim was to study 
Fig. 2. Relative size of the largest and second largest glomerulus. Comparison of the two largest glomeruli in the antennal lobes (ALs) of workers across 25 different Attini species (A) and among the small workers of nine different leaf-cutting Attini species (B). In order to compare the size of glomeruli among different ALs, we used a relative measure based on the variance found across all (or a large subset of) glomeruli: $\mathrm{R}_{\mathrm{V}}=\left(\mathrm{R}_{\mathrm{L}}-\mathrm{R}_{\mathrm{M}}\right) / \mathrm{SD}$. The dots show the $R_{V}$ of the largest and the triangles the $R_{V}$ of the second largest glomeruli for each species. A $R_{V}$ value of five (dotted line) was used to classify macroglomeruli (MG). Large workers of all leaf-cutting species possess an MG and in none of the antennal lobes of lower or higher Attini an MG was found (A). An MG was also absent in the ALs of small workers of four Atta and five Acromyrmex species (B).
A

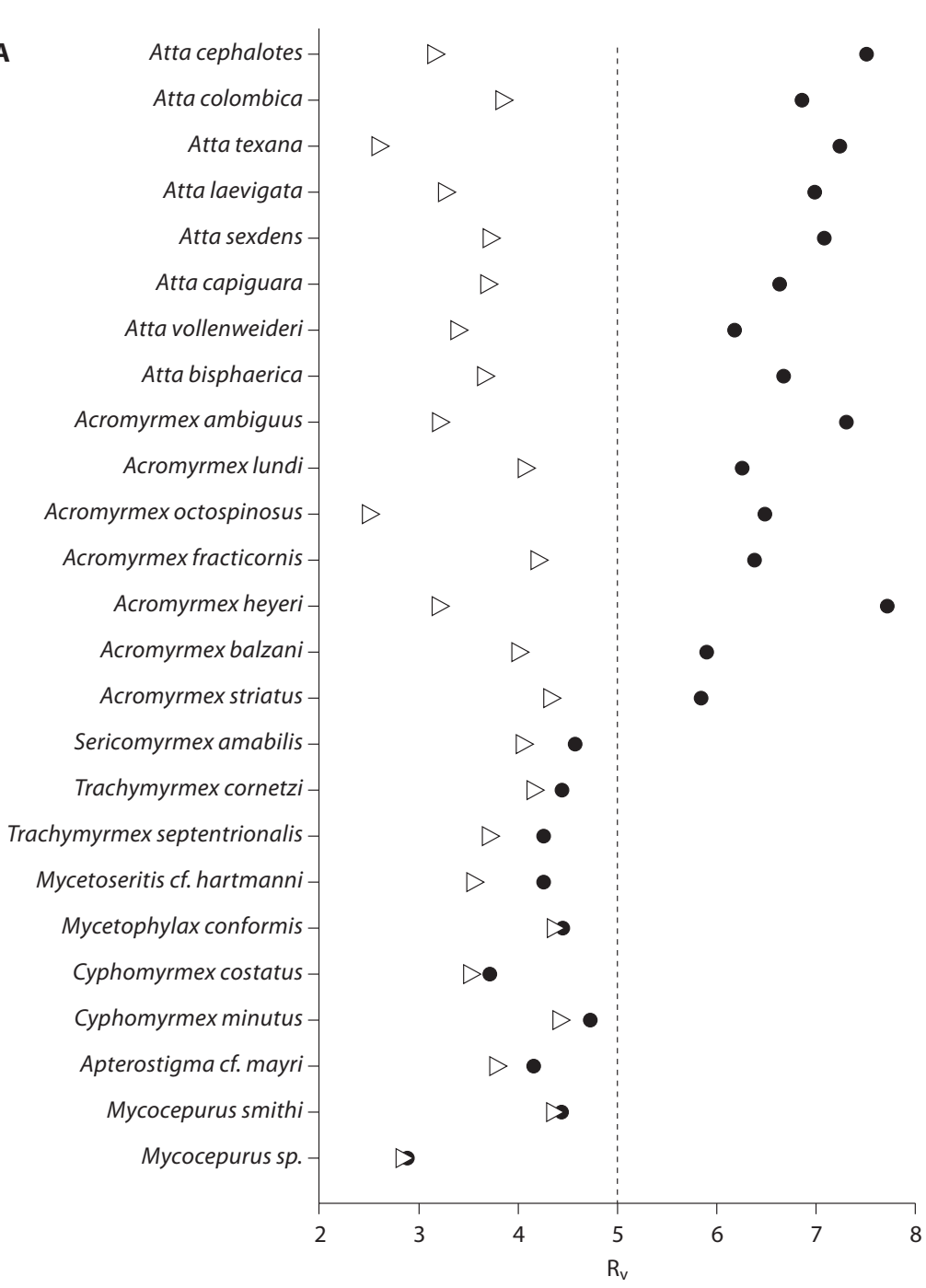

B

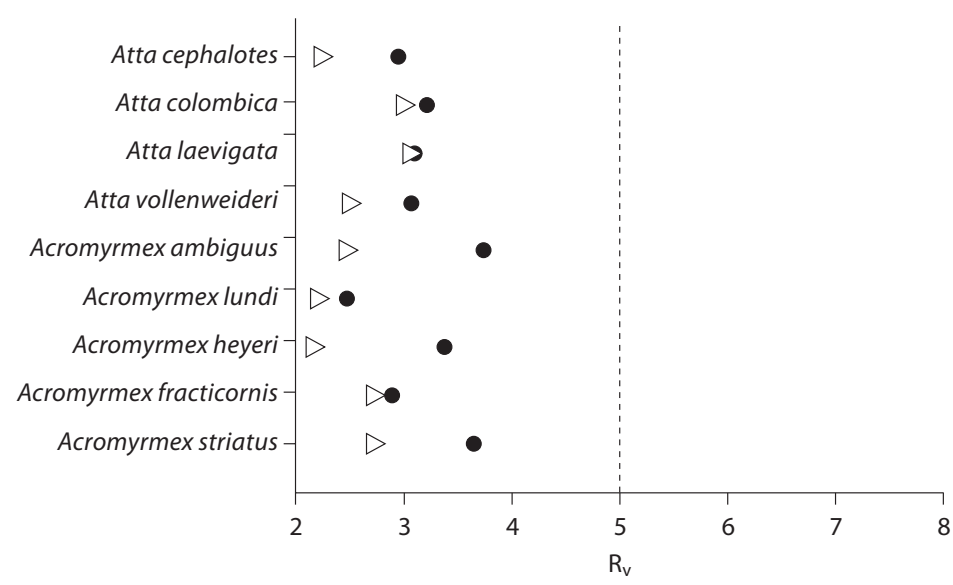


different species within the attine phylogeny to include a range of species with different olfactory-guided behaviors. Compared to other insect species the olfactory system of the Attini comprises large ALs with a high number of glomeruli. We found a large variability in neuroanatomical traits of the AL, for example in the number of glomeruli, and we expect that future studies will identify correlations between the number of glomeruli and distinct olfactory-guided behaviors across species. Extremely large glomeruli (MG) were found exclusively in one group of the Attini, the leaf-cutting Attini. This indicates that the MG is a derived over-expression of a trait in polymorphic leaf-cutting species. For a given species, phenotypic plasticity of this trait (MG in large workers and its absence in small workers) among castes is likely to promote division of labor in the leaf-cutting Attini [Kleineidam et al., 2007].

\section{High Number of Glomeruli and Its Potential Origin}

The ALs of the Attini are characterized by a large variance in the number of glomeruli which might reflect adaptations to species-specific demands on the olfactory system. We found the largest variance of the glomerular number in the five investigated genera of the lower Attini. In the higher and leaf-cutting Attini (a total of four genera), the variance is much lower. The lower Attini Ap. cf. mayri have more than twice the number of glomeruli compared to C. costatus which belongs to the same group. The 630 glomeruli found in the AL of Ap.cf. mayri, so far, is the highest number of glomeruli described for all insects with a similar organization of the olfactory pathway (except for the locust, in which AL glomeruli have been termed microglomeruli because of their different functional organization) [Hansson and Anton, 2000]. A historical and often cited number of $\sim 1000$ glomeruli in the hornet Vespa crabro [Hanström, 1928] is incorrect, as our closer inspection using confocal techniques revealed only about 250 glomeruli [Kelber, unpublished data]. Although we find a high number of glomeruli in all Attini, and also in other ant species such as Camponotus [Nishikawa et al., 2008; Zube et al., 2008], we cannot make predictions about the grade of social organization on the basis of glomerular number. Instead, we can assume that the high number of glomeruli, for instance in Ap. cf. mayri, indicates that their olfactory system is more differentiated compared to other species. This idea is also supported by the volume ratio between the ALs and the optic lobes (OLs). In most ant species, the visual processing is less prominent than the olfactory and pheromone processing [Gronenberg, 2008]. The AL volume in Ap. cf. mayri is 17 times larger than the OL volume, whereas in other lower and higher Attini this ratio is much smaller $(\sim 6-9$; see table 1). In the leaf-cutting Attini we also find a wide range for the AL/OL ratio $(\sim 4-16)$. Although the AL/OL ratio might relate to the relative importance of the olfactory sense, the high number of glomeruli is possibly another indication of its relevance.

We asked the question why there is such a large variability in the number of glomeruli across related species. It is assumed that the number of glomeruli corresponds to the number of ORN types and thus is related to the expression of different olfactory receptor genes. In Drosophila melanogaster, but also in humans, it was shown that only a subpopulation of an existing repertoire of OR genes is expressed [Hasin et al., 2008; Laissue and Vosshall, 2008]. The number of OR genes in the Attini is yet unknown. We found the two species with the highest and the lowest number of glomeruli at a phylogenetically basal position within the Attini. This could indicate that the common ancestor of the Attini possessed a high number of OR genes, and in the presently existing Attini - within all three groups - only a fractional number of them is expressed. We speculate that a high number of OR genes might have favored possible adaptations for the numerous olfactory-guided tasks that need to be successfully performed for fungus cultivation.

\section{The Macroglomerulus}

The size of a glomerulus is largely defined by the number of ORNs terminating in the glomerulus [Hansson et al., 1995; Berg et al., 1998]. A high number of ORNs probably leads to a higher absolute sensitivity for a particular odor (threshold sensitivity) and/or result in an improved signal to noise ratio. A high number of ORNs form terminal arborizations in the MG in A. vollenweideri and $A$. sexdens, and preliminary physiological results show that the releaser component of the trail pheromone is represented in the MG [Kleineidam et al., 2005, and unpublished data]. The MG probably plays a prominent role in the perception of the trail pheromone. The releaser component of the trail pheromone is sufficient to elicit trail following behavior, and several leaf-cutting Attini use the same releaser component [Tumlinson et al., 1971; Attygalle and Morgan, 1985; Kleineidam et al., 2007; Morgan, 2009]. The trail pheromones of the lower and higher Attini are not yet identified.

In the group of lower Attini, we investigated 7 species belonging to 5 out of 9 existing genera. In none of them did we find an MG. We also investigated three species of the higher Attini, two Trachymyrmex and one Sericomyr- 
mex species, which did not possess an MG. None of these species use an elaborate trail system or chemical mass recruitment, and the worker caste is monomorphic. A slight worker size variation was found for T. septentrionalis [Beshers and Traniello, 1996], but this was far less pronounced than in the leaf-cutting Attini. Although we did not investigate all lower and higher Attini species, our analyses of several genera within the lower and higher Attini make us confident that the described MG is restricted to the polymorphic leaf-cutting Attini. The genus Acromyrmex comprises $\sim 24$ species and is subdivided into the subgenera Acromyrmex s. Str. and Acromyrmex Moellerius [Fowler, 1988]. The genus Atta contains 15 highly polymorphic species, actually subdivided into the four following monophyletic groups, Atta s. str., Archeatta, Neoatta and Epiatta, a subdivision that slightly differs from a previous taxonomical division [Borgmeier, 1959; Bacci et al., 2009]. Our study covered species of all subgenera, and in all of the 15 investigated species we found an MG. This indicates that the existence of the MG is a derived over-expression of a trait and is restricted to the leaf-cutting Attini.

The existence of an MG is common in males of several insect species such as moths, cockroach and the honeybee [Boeckh et al., 1977; Arnold et al., 1985; Brockmann and Bruckner, 2001; Wanner et al., 2007]. The leafcutting Attini were the first and so far the only species in which an MG was found in the sterile worker caste [Kleineidam et al., 2005]. Until now, studies on the olfactory system in other species of ants did not reveal an MG in the female worker caste [Goll, 1967; Gronenberg and Hölldobler, 1999; Nishikawa et al., 2008]. It was shown by physiological and neuroanatomical data in the carpenter ant Camponotus floridanus that workers process information about the trail pheromone in regularly sized glomeruli [Zube et al., 2008]. But we cannot exclude the possibility that other ant species with a highly developed trail pheromone communication system also possess an MG. Eventually, the existence of a size polymorphism is the precondition for the over-expression of a glomerulus for trail pheromone components. It would be very interesting to investigate other ant species such as army ants or members of the Pheidole genus that show both a highly developed trail pheromone communication system as well as a pronounced size polymorphism.

\section{Position of the Macroglomerulus}

In moth species of the genus Heliothis it was found that the position of a glomerulus is conserved across closelyrelated species [Vickers et al., 1998; Vickers and Chris- tensen, 2003]. The same pheromone components are represented at the same position in an array of glomeruli (macroglomerular complex). This is possibly also the case for the MGs in the leaf-cutting Attini, where two different releaser components were identified for different species. The releaser component methyl-4-methylpyrrole-2carboxylate (M4MP2C) was found in A. cephalotes, A. texana and A. vollenweideri, and in Ac. octospinosus and Ac. subteraneus [Tumlinson et al., 1971; Nascimento et al., 1994; Tanaka et al., 2004; Morgan, 2009]. A different releaser component, 2-ethyl-3,6-dimethylpyrazine (2E3, 6DMP), was found in A. sexdens [Cross et al., 1979]. A. texana, A. vollenweideri and Ac. octospinosus have the same releaser component, and we found a similar MG position. A. cephalotes has an MG at a similar position as A. sexdens, but both use different releaser components. From this finding we conclude that the position of the MG in the different Atta and Acromyrmex species allows no clear prediction about the releaser component used by the species. The position close to the entrance of the antennal nerve, however, is conserved across all species that have an MG.

\section{A Macroglomerulus in Large Workers Only}

Small workers can be found on trails of different leafcutting Attini [Stradling, 1978; Wilson, 1980b; Whitehouse and Jaffe, 1996; Hughes and Goulson, 2001], and it was shown that they can perceive the trail pheromone components, although they do not possess an MG. There are differences, however, in the quality of perception of the trail pheromone, as demonstrated in behavioral experiments [Kleineidam et al., 2007]. We assume that in small workers the MG-corresponding glomerulus (responsible for the detection of the trail pheromonal releaser component) is located at a similar position in the $\mathrm{AL}$ as in large workers.

\section{The Macroglomerulus and Social Organization}

We propose that the MG is a specialization for a particular olfactory-guided foraging task: the trail-following behavior. This is supported by the fact that the size of the MG differs in different leaf-cutting species, and appears to correlate with their foraging system and their effectiveness in leaf-cutting. We find the least developed MG of all investigated species in Ac. striatus and Ac. balzani, both belonging to the subgenus Moellerius. Although most Acromyrmex species use large trail systems to supply their fungi with fresh plant material, Ac. striatus workers forage on less predictable resources and do not construct or maintain physical trails, using more loosely 
chemical trails instead [Carbonell, 1943; Bucher and Montenegro, 1974; Farji-Brener and Protomastro, 1992; Marschner et al., 1993]. Similarly, workers of Ac. balzani, a grass-cutting species with relatively small colony sizes, do usually employ short trails and a less complex chemical recruitment system [Fowler et al., 1986b; Lopes et al., $2003,2004]$. In contrast, we found the largest MG (nearly 14 times larger compared to the median of the volumes of all other glomeruli) in A. capiguara, which use extended underground and superficial trails to forage enormous amounts of grass [up to $196 \mathrm{~kg} /$ colony/year; Robinson and Fowler, 1982]. The presence of an MG, therefore, appears to be an adaptation to trail pheromone guided behavior of leaf-cutting Attini, and has reached the most prominent enlargement in species with an elaborate trail system.

Leaf-cutting Attini either forage mainly on grass (A. capiguara, A. bisphaerica, A. vollenweideri, Ac. balzani, Ac. fracticornis, Ac. striatus and Ac. heyeri) or forage on dicots (A. sexdens, A. cephalotes, A. colombica and Ac. lundi) [Fowler et al., 1986a]. It is assumed that one of both foraging preferences is basal and the other derived. Which of either represents the origin of leaf-cutting Attini is unclear [Weber, 1972; Fowler, 1982; Mayhe-Nunes and Jaffé, 1998]. Our analysis on the size of the $M G s\left(R_{v}\right.$ measure) revealed no correlation between $M G$ size and foraging preference. Rather we found similar variations in both groups with a $R_{v}$ from 5.8 to 7.7 in grass-cutting Attini, and $a R_{v}$ from 6.2 to 7.5 in dicot-cutting Attini. This suggests that the MG might have evolved prior to the diversification in substrate selection, and further emphasizes the strong plasticity of this over-expressed trait.

The larger the colony, the higher is its need for large amounts of substrate to supply the fungus. Fresh material such as leaves or grasses are available in a much larger amount and provide more energy compared to dead plant material. In order to cut and harvest fresh plant material efficiently, however, an ant worker has to have a critical size and strong mandibles. A single large worker is able to harvest more plant material than a whole group of small workers [Beshers and Traniello, 1996]. On the other hand, small workers are needed inside the nest for fungus care and for the delicate handling of the fungus hyphae to feed the larvae. These distinct tasks that need to be fulfilled by leaf-cutting ant workers in a colony probably promoted the evolution of worker polymorphism. Although a flexible division of labor within the worker caste is common in most social insects, the polymorphism constrains the flexibility of, for instance, task switching. As a consequence, workers become special- ized for particular tasks, and specific adaptations might further support this specialization. The MG in large workers of Atta and Acromyrmex is such an adaptation with probable great impact on both the processing of odor information, and the responsiveness of large workers to odor stimuli. Thus, the neuroanatomical differences between small and large workers support the alloethism in polymorphic species and add on to the complexity of their social organization.

In the past, behavioral, ecological, morphological and genetic characters have been used to categorize the tribe Attini into three major groups (lower, higher and leafcutting Attini). This is the first study that compared neuroanatomical traits within this monophyletic but behaviorally diverse group of ants. The results show that one group, the leaf-cutting Attini, is separated based on a unique neuroanatomical trait, the MG. It is expected that future studies on the behavioral ecology of attine species will highlight the behavioral significance of other neuroanatomical characters described in this study.

\section{Acknowledgements}

We thank L. Forti (UNESP, Botucatu) for support during specimen sampling in Brazil, and A. G. Di Giacomo and family Götz for allowing the collection of leaf-cutting ants at the Reserva Ecológica El Bagual (Alparamis SA - Aves Argentinas) in Formosa, Argentina. We thank M. Bollazzi, H. Herz, U. Mueller, J. Liebig and R. Wirth for collecting and fixating different Attini for the ant collection of the Department of Behavioral Physiology and Sociobiology, University of Würzburg. We thank P. D'Ettorre, M.Schiøtt, H.H. de Fine Licht and F.J. Guerrieri from the University of Copenhagen for the collection, fixation and provision with different attine species. We also thank A. Gerber-Kurz and A. Laudahn for the supply of leaf-cutting Attini colonies at our laboratory. This work was funded by the Deutsche Forschungsgesellschaft (DFG) SFB 554/A6.

References

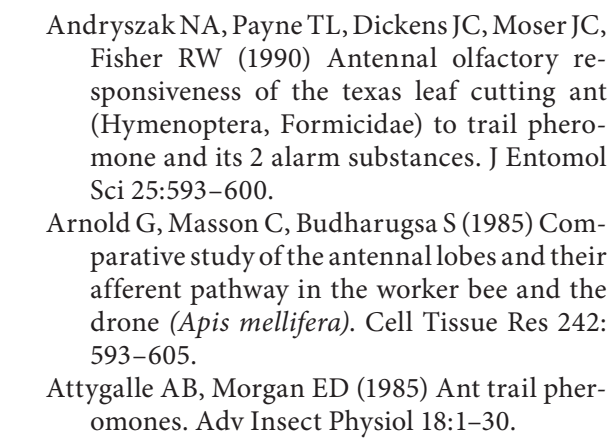

Kelber/Rössler/Roces/Kleineidam 
Bacci M, Solomon SE, Silva-Pinhati ACO, Mueller UG, Martins VG, Carvalho AOR, Vierira LGE (2009) Phylogeny of leafcutter ants in the genus Atta Fabricius (Formicidae: Attini) based on mitochondrial and nuclear DNA sequences. Mol Phylogenet Evol, in press.

- Berg BG, Almaas TJ, Bjaalie JG, Mustaparta H (1998) The macroglomerular complex of the antennal lobe in the tobacco budworm moth Heliothis virescens: specified subdivision in four compartments according to information about biologically significant compounds. J Comp Physiol A 183:669-682.

- Beshers SN, Traniello JFA (1996) Polyethism and the adaptiveness of worker size variation in the attine ant Trachymyrmex septentrionalis. J Insect Behav 9:61-83.

Boeckh J, Boeckh V, Kühn A (1977) Further data on the topography and physiology of central olfactory neurons in insects. In: Olfaction and Taste VI (Le Magnen J, MacLeod P, eds), pp 315-321. London: Information Retrieval Ltd.

Borgmeier T (1959) Revision der Gattung Atta Fabricius (Hymenoptera, Formicidae). Studia Ent 2:321-391.

- Brockmann A, Bruckner D (2001) Structural differences in the drone olfactory system of two phylogenetically distant Apis species, $A$. florea and $A$. mellifera. Naturwissenschaften 88:78-81.

Bucher EH, Montenegro R (1974) Hábitos forrajeros de cuatro hormigas simpátridas del género Acromyrmex (Hymenoptera, Formicidae). Ecología 2:47-53.

Carbonell CS (1943) Las hormigas cortadoras del Uruguay. Rev Asoc Ing Agrónomos Montevideo 15:30-39.

-Cross JH, Byler RC, Ravid U, Silverstein RM, Robinson SW, Baker PM, Sabinodeoliveira J, Jutsum AR, Cherrett JM (1979) Major component of the trail pheromone of the leaf-cutting ant, Atta sexdens rubropilosa Forel - 3-Ethyl-2,5-Dimethylpyrazine. J Chem Ecol 5:187-203.

-Currie CR, Scott JA, Summerbell RC, Malloch D (1999) Fungus-growing ants use antibioticproducing bacteria to control garden parasites. Nature 398:701-704.

-Esslen J, Kaissling KE (1976) Number and distribution of sensilla on antennal flagellum of honeybee (Apis mellifera L). Zoomorphologie 83:227-251.

Farji-Brener AG, Protomastro J (1992) Patrones forrajeros de dos especies simpátricas de hormigas cortadoras de hojas (Attini, Acromyrmex) en un bosque subtropical seco. Ecotropicos 5:32-43.

- Flanagan D, Mercer AR (1989) An atlas and 3-D reconstruction of the antennal lobes in the worker honey bee, Apis mellifera L (Hymenoptera, Apidae). J Insect Morphol Embryol 18:145-159.

Fowler HG (1982) Habitat effect on fungal substrate selection by a leaf-cutting ant. J New York Entomol Soc 90:64-69.
Fowler HG (1988) Taxa of the neotropical grasscutting ants, Acromyrmex (Moellerius) (Hymenoptera: Formicidae: Attini). Cientifica 16:281-295.

Fowler HG, Forti LC, Pereira da Silva V, Saes NB (1986a) Economics of grass-cutting ants. In: Fire Ants and Leaf-Cutting Ants: Biology and Management (Lofgren CS, Vander Meer RK, eds), pp 18-35. Boulder, CO: Westview Press.

Fowler HG, Pereira da Silva V, Forti LC, Saes NB (1986b) Population dynamics of leaf-cutting ants: a brief review. In: Fire Ants and LeafCutting Ants: Biology and Management (Lofgren CS, Vander Meer RK, eds), pp 123 145. Boulder, CO: Westview Press.

-Galizia CG, McIlwrath SL, Menzel R (1999a) A digital three-dimensional atlas of the honeybee antennal lobe based on optical sections acquired by confocal microscopy. Cell Tissue Res 295:383-394.

Galizia CG, Sachse S, Rappert A, Menzel R (1999b) The glomerular code for odor representation is species specific in the honeybee Apis mellifera. Nature Neurosci 2:473-478.

Goll W (1967) Strukturuntersuchungen am Gehirn von Formica. Z Morphol Ökol Tiere 59: 143-210.

Gronenberg W (2008) Structure and function of ant (Hymenoptera, Formicidae) brains: Strength in numbers. Myrmecol News 11: 25-36.

Gronenberg W, Hölldobler B (1999) Morphologic representation of visual and antennal information in the ant brain. J Comp Neurol 412:229-240.

Hansson BS, Almaas TJ, Anton S (1995) Chemical communication in heliothine moths: 5 . antennal lobe projection patterns of pheromone-detecting olfactory receptor neurons in the male Heliothis virescens (Lepidoptera, Noctuidae). J Comp Physiol A 177:535-543.

Hansson BS, Anton S (2000) Function and morphology of the antennal lobe: New developments. Annu Rev Entomol 45:203-231.

Hanström B (1928) Vergleichende Anatomie des Nervensystems der wirbellosen Tiere. Berlin: Springer-Verlag.

Hasin Y, Olender T, Khen M, Gonzaga-Jauregui C, Kim PM, Urban AE, Snyder M, Gerstein MB, Lancet D, Korbel JO (2008) High-resolution copy-number variation map reflects human olfactory receptor diversity and evolution. Plos Genet 4.

Hölldobler B, Wilson EO (1990) The Ants. Cambridge, MA: The Belknap Press of Harvard University.

Huetteroth W, Schachtner J (2005) Standard three-dimensional glomeruli of the Manduca sexta antennal lobe: a tool to study both developmental and adult neuronal plasticity. Cell Tissue Res 319:513-524.

Hughes WOH, Goulson D (2001) Polyethism and the importance of context in the alarm reaction of the grass-cutting ant, Atta capiguara. Behav Ecol Sociobiol 49:503508.
Ignell R, Dekker T, Ghaninia M, Hansson BS (2005) Neuronal architecture of the mosquito deutocerebrum. J Comp Neurol 493:207240.

- Joerges J, Kuttner A, Galizia CG, Menzel R (1997) Representations of odours and odour mixtures visualized in the honeybee brain. Nature 387:285-288

Kelber C, Rossler W, Kleineidam CJ (2006) Multiple olfactory receptor neurons and their axonal projections in the antennal lobe of the honeybee Apis mellifera. J Comp Neurol 496: 395-405.

Kleineidam C, Rössler W (2009) Adaptations in the olfactory system of social Hymenoptera. In: Organization of Insect Societies (Gadau J, Fewell J, eds), pp 194-219. Cambridge, MA: Harvard University Press.

Kleineidam CJ, Obermayer M, Halbich W, Rössler W (2005) A macroglomerulus in the antennal lobe of leaf-cutting ant workers and its possible functional significance. Chem Senses 30:383-392.

- Kleineidam CJ, Rossler W, Holldobler B, Roces F (2007) Perceptual differences in trail-following leaf-cutting ants relate to body size. J Insect Physiol 53:1233-1241.

- Laissue PP, Reiter C, Hiesinger PR, Halter S, Fischbach KF, Stocker RF (1999) Three-dimensional reconstruction of the antennal lobe in Drosophila melanogaster. J Comp Neurol 405:543-552.

-Laissue PP, Vosshall LB (2008) The olfactory sensory map in Drosophila. Adv Exp Med Biol 628:102-114

- Leal IR, Oliveira PS (2000) Foraging ecology of attine ants in a Neotropical savanna: seasonal use of fungal substrate in the cerrado vegetation of Brazil. Insectes Sociaux 47:376382

Lopes JFS, Camargo RS, Forti LC (2003) Foraging behavior and subtask hierarchical structure in Acromyrmex spp. (Hymenoptera: Formicidae). Sociobiology 42:781-793.

-Lopes JFS, Orti LCF, Camargo RS (2004) The influence of the scout upon the decision-making process of recruited workers in three $A c$ romyrmex species (Formicidae: Attini). Behav Proc 67:471-476.

- Mackay WP, Maes JM, Fernandez PR, Luna G (2004) The ants of North and Central America: the genus Mycocepurus (Hymenoptera: Formicidae). J Insect Sci 4:1-7.

Marschner J, Machado V, Diehl-Fleig E (1993) Variação anual na atividade de corte de $A c$ romyrmex striatus (Formicidae, Attini). Acta Biol Leopoldensia 15:77-86.

Mayhe-Nunes AJ, Jaffé K (1998) On the biogeography of Attini (Hymenoptera: Formicidae). Ecotropicos 11:45-54

- Mombaerts P, Wang F, Dulac C, Chao SK, Nemes A, Mendelsohn M, Edmondson J, Axel R (1996) Visualizing an olfactory sensory map. Cell 87:675-686.

Morgan ED (2009) Trail pheromones of ants. Physiol Entomol 34:1-17. 
Morgan ED, Keegans SJ, Tits J, Wenseleers T, Billen J (2006) Preferences and differences in the trail pheromone of the leaf-cutting ant Atta sexdens sexdens (Hymenoptera: Formicidae). Eur J Entomol 103:553-558.

- Mueller UG, Schultz TR, Currie CR, Adams RMM, Malloch D (2001) The origin of the attine ant-fungus mutualism. Q Rev Biol 76: 169-197.

-Mueller UG, Wcislo WT (1998) Nesting biology of the fungus-growing ant Cyphomyrmex longiscapus Weber (Attini, Formicidae). Insectes Sociaux 45:181-189.

- Nascimento RRD, Morgan ED, Moreira DDO, Dellalucia TMC (1994) Trail pheromone of leaf-cutting ant Acromyrmex subterraneus subterraneus (Forel). J Chem Ecol 20:17191723.

Dishikawa M, Nishino H, Misaka Y, Kubota M, Tsuji E, Satoji Y, Ozaki M, Yokohari F (2008) Sexual dimorphism in the antennal lobe of the ant Camponotus japonicus. Zool Sci 25: 195-204.

Robertson HM, Wanner KW (2006) The chemoreceptor superfamily in the honey bee, Apis mellifera: Expansion of the odorant, but not gustatory, receptor family. Genome Res 16: 1395-1403.

Robinson SW, Fowler HG (1982) Foraging and pest potential of paraguayan grass-cutting ants (Atta and Acromyrmex) to the cattle industry. J Appl Entomol 93:42-54.

Roces F, Lighton JRB (1995) Larger bites of leafcutting ants. Nature 373:392-393.

Rodrigues V (1988) Spatial coding of olfactory information in the antennal lobe of Drosophila melanogaster. Brain Res 453:299-307.

Röschard J, Roces F (2002) The effect of load length, width and mass on transport rate in the grass-cutting ant Atta vollenweideri. Oecologia 131:319-324.

Röschard J, Roces F (2003) Cutters, carriers and transport chains: Distance-dependent foraging strategies in the grass-cutting ant Atta vollenweideri. Insectes Sociaux 50:237-244.
Sachse S, Rappert A, Galizia CG (1999) The spatial representation of chemical structures in the antennal lobe of honeybees: steps towards the olfactory code. Eur J Neurosci 11: 3970-3982.

Sandoz JC (2006) Odour-evoked responses to queen pheromone components and to plant odours using optical imaging in the antennal lobe of the honey bee drone Apis mellifera L. J Exp Biol 209:3587-3598.

Schneider D, Steinbrecht RA (1968) Checklist of insect olfactory sensilla. Symp Zool Soc Lond 23:279-297.

Schultz TR, Brady SG (2008) Major evolutionary transitions in ant agriculture. Proc Nat Acad Sci 105:5435-5440.

Schultz TR, Meier R (1995) A phylogenetic analysis of the fungus-growing ants (Hymenoptera: Formicidae: Attini) based on morphological characters of the larvae. Syst Entomol 20:337-370.

Stocker RF (1994) The organisation of the chemosensory system in Drosophila melanogas ter. Cell Tissue Res 275:3-26.

Stradling DJ (1978) Influence of size on foraging in ant, Atta cephalotes, and effect of some plant defence mechanisms. J Anim Ecol 47: 173-188.

Tanaka NK, Awasaki T, Shimada T, Ito K (2004) Integration of chemosensory pathways in the Drosophila second-order olfactory centers. Curr Biol 14:449-457.

Tumlinson J, Silverstein RM, Moser JC, Brownlee RG, Ruth JM (1971) Identification of trail pheromone of a leaf-cutting ant, Atta texana. Nature 234:348-349.

Tumlinson J, Silverstein RM, Ruth JM, Brownlee RG, Moser JC (1972) Volatile trail pheromone of leaf-cutting ant, Atta texana. J Insect Physiol 18:809-814.

-Vassar R, Chao SK, Sitcheran R, Nunez JM, Vosshall LB, Axel R (1994) Topographic organization of sensory projections to the olfactory-bulb. Cell 79:981-991.

Vickers NJ, Christensen TA (2003) Functional divergence of spatially conserved olfactory glomeruli in two related moth species. Chem Senses 28:325-338.
-Vickers NJ, Christensen TA, Hildebrand JG (1998) Combinatorial odor discrimination in the brain: Attractive and antagonist odor blends are represented in distinct combinations of uniquely identifable glomeruli. J Comp Neurol 400:35-56.

Vosshall LB, Wong AM, Axel R (2000) An olfactory sensory map in the fly brain. Cell 102: 147-159.

-Wanner KW, Nichols AS, Walden KKO, Brockmann A, Luetje CW, Robertson HM (2007) A honey bee odorant receptor for the queen substance 9-oxo-2-decenoic acid. Proc Natl Acad Sci 104:14383-14388

Weber NA (1956) Fungus-growing ants and their fungi - Trachymyrmex septentrionalis. Ecology 37:150-161.

Weber NA (1972) Gardening Ants. Philadelphia, PA: American Philosophical Society.

-Wetterer JK, Schultz TR, Meier R (1998) Phylogeny of fungus-growing ants (Tribe Attini) based on mtDNA sequence and morphology. Mol Phylogenet Evol 9:42-47.

Whitehouse MEA, Jaffe K (1996) Ant wars: Combat strategies, territory and nest defence in the leaf-cutting ant Atta laevigata. Anim Behav 51:1207-1217.

Wilson EO (1971) The insect societies. Cambridge, MA: Belknap Press of Harward University.

Wilson EO (1980a) Caste and division of labor in leaf-cutter ants (Hymenoptera, Formicidae, Atta). 1. The overall pattern in Atta sexdens. Behav Ecol Sociobiol 7:143-156.

Wilson EO (1980b) Caste and division of labor in leaf-cutter ants (Hymenoptera, Formicidae, Atta). 2. The ergonomic optimization of leafcutting. Behav Ecol Sociobiol 7:157-165.

Zube C, Kleineidam CJ, Kirschner S, Neef J, Rössler W (2008) Organization of the olfactory pathway and odor processing in the antennal lobe of the ant Camponotus floridanus. J Comp Neurol 506:425-441. 